\title{
Wielki apetyt na "miniburgera" O problemach opracowania komiksów w formacie MARC 21
}

Streszczenie. Od 2007 roku Biblioteka Uniwersytecka w Poznaniu gromadzi komiksy oraz materiały ich dotyczące. Momentem znaczącym dla gromadzenia tych wydawnictw był zakup prywatnej kolekcji 4670 komiksów. Niniejszy artykuł definiuje pojęcie „komiks" oraz omawia trudności, jakie napotykają katalogerzy w opracowaniu formalnym tego trudnego materiału. Autorki porównały rozwiązania zastosowane w innych bibliotekach. Przedstawiły również stan prac nad katalogowaniem komiksów w Bibliotece Uniwersyteckiej w Poznaniu. Artykuł zawiera przykłady i propozycje konkretnych rozwiązań.

SŁowA KLUCzowe: komiksy, katalogowanie.

Czym jest komiks? Niektórzy określają go mianem „dziewiątej sztuki”, inni spychają na margines kultury. Niezaprzeczalnie jednak takie zjawisko istnieje, jakkolwiek w Polsce, w porównaniu z Europą Zachodnią czy Stanami Zjednoczonymi, budzi wciąż wiele kontrowersji ${ }^{2}$. Według Scotta McClouda pojęcie „komiks” jest pojęciem trudnym, ale wartym zdefiniowania. Jego zdaniem komiks to pewna liczba pomysłów i wizerunków, sekwencyjna sztuka wizualna, w której najważniejsza jest przestrzeń ${ }^{3}$.

\footnotetext{
${ }^{1}$ Miniburger - seria 12 książeczek komiksowych stworzonych przez międzynarodową parszywą trzynastkę - international dirty dozen (pięciu Słoweńców, dwóch Włochów, dwóch Serbów, jeden Bośniak, jeden Francuz i jeden Anglik).

${ }^{2}$ Zainteresowanych historią komiksu odsyłamy do następujących pozycji: J. Szyłak, Komiks. Świat przerysowany, Gdańsk 1998; K.T. Toeplitz, Sztuka komiksu: próba definicji nowego gatunku artystycznego, Warszawa 1985; J. Szyłak, Komiks, Kraków 2000; H. Ronek, Komiks w Polsce na przełomie tysiacleci, czyli sytuacja polskiego rynku komiksowego lat 90., z. 1, [s.1.] 1999.

${ }^{3}$ S. McCloud, Understanding comics: the invisible art, wyd. 2, Northampton 1993, s. 1-7.
} 
W wyszukiwarkach internetowych i encyklopediach drukowanych można natrafić na definicję następującej treści: „Komiks to rysunkowa historyjka obrazkowa, zwykle o charakterze humorystycznym, przygodowym lub sensacyjnym oraz (zazwyczaj) niewielkich wartościach artystycznych" ${ }^{4}$.

Ta definicja utrwaliła się mocno $\mathrm{w}$ umysłach wielu polskich czytelników, którzy komiksy nadal traktują z lekceważeniem. W wielu kręgach społecznych uważa się owo zjawisko za kolejną tanią rozrywkę dla półanalfabetów ${ }^{5}$.

Inaczej jest we Francji, gdzie komiks traktowany jest na równi z literaturą poważną i należy do kanonu szkolnych lektur obowiązkowych. Jeszcze poważniej podchodzi się do niego w Japonii - tam jego powszechność jest chyba największa na całym globie - czyta go każdy codziennie jak gazetę ${ }^{6}$.

Częste używanie tego słowa, przy zaznaczonych już, zazwyczaj deprecjonujących konotacjach wartościujących, doprowadziło dość skutecznie do zatarcia konturów samego zjawiska, co utrudnia zbudowanie jego przekonującej definicji. Istnienie zaś takiej definicji pozwala określić zakres historyczny komiksu, jego stosunek do prekursorów gatunku oraz przynajmniej niektóre cechy wyróżniające. Komiksy rozwijają się i zmieniają nieustannie, co sprawia, iż kolejne definicje stają się niepełne bądź zbyt wąskie. W niektórych encyklopediach, dla przykładu w encyklopedii Larousse'a z 1966 roku, nie notuje się haseł związanych z komiksem, natomiast w Słowniku wyrazów obcych z 1961 roku znaleźć można bardzo ogólną definicję, określającą go jako „opowiadanie, nowelę lub powieść przedstawioną za pomocą obrazków, z krótkimi objaśnieniami ich treści”. W The Columbia Encyclopaedia z 1954 roku funkcjonuje hasło, według którego comics strip jest połączeniem karykatury z linią narracyjną (story line), ułożonym w serię obrazków na stronie i dotyczącym tych samych postaci lub zbioru postaci. W dalszej części definicji autorzy podają zarys historyczny komiksu amerykańskiego ${ }^{7}$.

Pojęcie "komiks" powstało przez połączenie angielskich wyrazów comic $=$ komiczny i strip $=$ pasek (dosłownie: komiczny pasek). $\mathrm{W}$ języku francuskim odpowiednikiem jest BD (la bande dessinée), we włoskim fumet$t i, \mathrm{w}$ niemieckim najczęściej stosuje się formę angielską comics lub comics

${ }^{4}$ S. Fiedkiewicz, Bolesna historia, "Tygodnik Polski" [online], [dostęp: 22.05.2010], dostępny w Internecie: http://content.yudu.com/Library/A1nq8g/TygodnikPolski96/ resources/18.htm.

${ }^{5}$ W. Obremski, Krótka historia sztuki komiksu w Polsce 1945-2003, Toruń 2005, s. 8.

${ }^{6}$ A. Stasińska, Komiks - sztuka niedoceniona, „Tygiel Kultury” 2007, nr 7-9, s. 165-172 .

${ }^{7}$ K.T. Toeplitz, op.cit., s. 10. 
strip ${ }^{8}$. Obraz i słowo to podstawowe składniki komiksu. Niektórzy autorzy zastanawiają się, czy prawdziwy komiks może mieć rozbudowane partie tekstowe, czy też powinien ograniczyć się do dymków i onomatopei ${ }^{9}$.

Tu nasuwa się pytanie zadawane przez katalogujących bibliotekarzy: słowo czy obraz, który z tych dwóch elementów jest ważniejszy? Czy pomysłodawcę scenariusza traktować jako twórcę dzieła, a ilustratora jako jego dopełnienie, czy odwrotnie? Tematem szerzej zajmiemy się w dalszej części artykułu.

Współczesny teoretyk komiksu, dr hab. Jerzy Szyłak, wyróżnia trzy odmiany komiksu:

- pierwsza ma charakter współczesnego folkloru miejskiego; wykorzystywane są tu stereotypowe fabuły, oparte na podstawowych wartościach moralnych; kreowani bohaterowie mają cechy mitologiczne i nadprzyrodzone (np. Superman, Batman);

- w drugi rodzaj wpisują się dwie odmiany: świadome wykorzystywanie środków sztuk plastycznych, literatury, filmu czy fotografii, a następnie ich twórcze przekształcenie, lub też tworzenie pozornie niestarannych i nieudolnych form, podważających wszelkie tabu i kpiących z mieszczańskiej moralności - underground comics;

- trzeci rodzaj to pojawiające się w prasie kilkuobrazkowe, humorystyczne opowiadania o charakterze cyklicznym (np. Fistaszki).

Komiksy powstają jako teksty samodzielne, ale mogą też być tworzone na podstawie książek, filmów lub innych dzieł sztuki - i na odwrót. Poza tym termin „komiksowość" stosuje się do określenia fragmentarycznego budowania narracji, specyficznego montażu ujęć w filmie bądź cyklu fotografii. Krótkie historie komiksowe nadal umieszczane są w czasopismach, większe serie - w albumach, a w ostatnich latach, oprócz wersji papierowej, powstało wiele komiksów sieciowych, ukazujących się w Internecie.

Na przełomie października i listopada 2007 roku - w związku z faktem, że Biblioteka Uniwersytecka w Poznaniu jest biblioteką naukową, której jednym z głównych celów jest zapewnienie wysokiej jakości merytorycznej zbiorów - zauważono potrzebę gromadzenia (dla celów naukowych i badawczych) komiksów. Spowodowało to zmianę polityki zarządzania zasobami, zgodnie z którą Biblioteka Uniwersytecka i inne właściwe biblioteki wydziałowe mają gromadzić wybrane tytuły komiksów oraz materiały ich dotyczące, jako źródła pierwotne do prowadzenia badań naukowych i dydaktyki ${ }^{10}$. Biblioteka Uniwersytecka jest kolejną,

\footnotetext{
${ }^{8}$ Ibidem, s. 6-7.

${ }^{9}$ A. Stasińska, op.cit., s. 165-172.

${ }^{10}$ Zarządzenie wewnętrzne Dyrektora Biblioteki Uniwersyteckiej nr 4/2008 z 26.11.2008 w sprawie polityki zarządzania zasobami w systemie biblioteczno-informacyjnym UAM.
} 
obok Biblioteki Narodowej w Warszawie oraz Wojewódzkiej i Miejskiej Biblioteki Publicznej w Gdańsku, biblioteką naukową, która stworzyła kolekcję komiksów. Obecnie ${ }^{11}$ posiada ponad 5000 woluminów, na które składają się zarówno komiksy, jak i opracowania polskie i zagraniczne dotyczące tematyki komiksowej. Jest to drugi (po Pracowni Komiksowej WiMBP w Gdańsku) systematycznie prowadzony zbiór w Polsce ${ }^{12}$.

Gromadzenie komiksów i literatury ich dotyczącej przyniosło Bibliotece Uniwersyteckiej wiele korzyści:

- komiksy są cennym źródłem wiedzy dla studentów i badaczy literatury, historii i zjawisk kulturowych;

- Biblioteka mogła rozszerzyć ofertę kulturalno-edukacyjną, czego wyrazem są m.in. dwie wystawy zorganizowane w ciągu jednego roku: „45-89 Komiks za żelazną kurtyną” (kwiecień 2009) i „Kadrowana rzeczywistość/rozrysowana wyobraźnia. Komiksy z kolekcji Biblioteki Uniwersyteckiej w Poznaniu" (luty 2010), międzynarodowa konferencja naukowa „Przestrzenie kultury komiksowej” (4-5 lutego 2010) czy bezpośrednie zaangażowanie się Biblioteki w Festiwal Kultury Komiksowej „Ligatura” (4-7 lutego 2010);

- wzrost liczby zainteresowanych czytelników.

Naszą przygodę z komiksami rozpoczęliśmy od wspomnianej zmiany polityki gromadzenia tego typu materiałów oraz od zakupu prywatnej kolekcji 4670 komiksów, które sukcesywnie uzupełniamy o to wszystko, co jest wartościowe i znaczące dla naszych zbiorów. Zdaniem dra Rafała Wójcika, osoby odpowiedzialnej za gromadzenie komiksów, posiadamy obecnie około 80\% tego, co ukazało się w Polsce od lat 50. XX wieku jako dokumenty samodzielne wydawniczo. Ostateczną liczbę poznamy jednak po skonfrontowaniu całości z wydaną w 2010 roku bibliografią Marka Misiory $^{13}$. Zważywszy na fakt, iż apetyt rośnie w miarę jedzenia, Biblioteka Uniwersytecka postanowiła uzupełnić kolekcję o tytuły zagraniczne, wartościowe artystycznie i kulturowo oraz nagradzane na ważnych konkursach i festiwalach, takich jak: Festival International de la Bande Dessinée d'Angoulęme, Festival de la BD francophone de Québek, Comic-Con i Nagroda Willa Eisnera (Will Eisner Comic Industry Award).

Zrąb główny stanowią wpływy z egzemplarza obowiązkowego. Poza tym Biblioteka kupuje tytuły znaczące dla nauki i kultury oraz otrzymuje

\footnotetext{
${ }^{11}$ Stan na kwiecień 2010 roku.

${ }^{12}$ Strona internetowa Biblioteki Uniwersyteckiej w Poznaniu [online], [dostęp: 12.05.2010], dostępny w Internecie: http://lib.amu.edu.pl/index.php?option=com_content\&task=view\&id=952\&Itemid=164.

${ }^{13}$ M. Misiora, Bibliografia komiksów wydanych w Polsce w latach 1905(1859*)-1999: albumy, magazyny, komiksy z gazet, ksiażki o komiksie, Poznań 2010.
} 
dary. Biblioteka Uniwersytecka jest instytucją naukowa, więc z reguły nie gromadzi komiksów dziecięcych, wyjąwszy klasykę gatunku. Literaturę dziecięca gromadzi Biblioteka Raczyńskich w Poznaniu. Posiadamy wiele komiksów z Europy Środkowej (Czechy, Słowenia, Łotwa), jak również wartościowe dla naszych badań tytuły z Francji, Belgii, Stanów Zjednoczonych i innych.

Gromadzenie komiksów jest wyzwaniem, gdyż w tej produkcji trzeba być bardzo dobrze zorientowanym, by wybrać tytuły wartościowe, interesujące dla badaczy i studentów. Ale sam dobór zasobów to dopiero pierwszy etap pracy. Kolejny, trudny, stanowi opracowanie zgromadzonych dokumentów.

Trudności stwarza już sama liczba komiksów, a zwłaszcza ich różnorodność i specyfika. Jednym z ważniejszych problemów, z którymi się zetknęliśmy, był brak normy zawierającej przepisy ich katalogowania. W związku z tym należało zastanowić się, co trzeba zrobić, by zgromadzone dokumenty zostały opracowane właściwie. Ostatecznie postanowiono, że wszystkie komiksy, które nie są dokumentami ciągłymi, będą traktowane jako dokumenty zwarte, czyli samoistne wydawniczo, a co za tym idzie, tak samo katalogowane jak wszystkie dokumenty tego typu. Biblioteka pracuje w systemie Horizon $7.3 \mathrm{w}$ formacie MARC 21. Podstawą opisu bibliograficznego komiksów jest norma PN-82/N-0152-1/A1:1997 Opis bibliograficzny. Ksiażki (Zmiana A1), która jest zgodna z zaleceniami międzynarodowymi International Standard Bibliographic Description for Monographic Publications ISBD(M).

Podczas opracowywania komiksów bardzo często napotykamy różne trudności, jak np. odpowiedni dobór haseł, interpretacje danych wydawniczych, rozróżnienie wydawnictw zwartych od ciągłych. W związku z tym postanowiłyśmy skontaktować się z innymi bibliotekami w Polsce (Biblioteka Narodowa w Warszawie, Pracownia Komiksowa w Gdańsku, Biblioteka Publiczna w Złotowie), które gromadzą komiksy, by dowiedzieć się, w jaki sposób radzą sobie z tymi zagadnieniami.

Biblioteka Narodowa w Warszawie gromadzi komiksy od lutego 2008 roku na podstawie egzemplarza obowiązkowego, przy czym są to głównie komiksy polskie, które rejestruje „Przewodnik Bibliograficzny”. Gromadzeniem zajmuje się Zakład Gromadzenia i Uzupełniania Zbiorów. Opisy wprowadzane są w systemie bibliotecznym INNOPAC/MILLENNIUM w formacie MARC 21. O doborze hasła decyduje głównie układ danych na stronie tytułowej, przy czym w większości przypadków jest to ilustrator, chyba że wydawca umieści na pierwszym miejscu autora tekstu - wówczas to on występuje w haśle głównym. Na pytanie dotyczące umieszczenia w rekordzie bibliograficznym haseł innych osób - wypeł- 
niaczy tuszu, osób odpowiedzialnych za kolory i rysunek ołówkiem, za wypełnianie dymków - uzyskałyśmy odpowiedź, iż najczęściej w opisie są one pomijane ${ }^{14}$.

Pracownia Komiksowa w Gdańsku posiada kolekcję około 4000 woluminów. Gromadzeniem komiksów zajmuje się Pracownia Komiksowa (dary od wydawców) oraz Dział Gromadzenia Wojewódzkiej i Miejskiej Biblioteki Publicznej w Gdańsku (zakupy). Opracowanie komiksów odbywa się przy użyciu programu PATRON. Pracownicy biblioteki umieszczają w haśle głównym scenarzystę, uważając, iż tylko instytucje artystyczne powinny podać ilustratora $\mathrm{w}$ haśle głównym (pole 100). W przypadku, kiedy w komiksie występuje wielu autorów lub kiedy jest on wydaniem albumowym, katalogujący umieszczają w polu odpowiedzialności redaktora. Podobnie jak w naszej bibliotece, katalogujący twierdza, iż nie powinno się katalogować wydań komiksowych jak książek ${ }^{15}$.

Miejska Biblioteka w Złotowie - gromadzeniem komiksów zajmuje się dyrektor Biblioteki oraz bibliotekarz z Działu Gromadzenia, przy czym $\mathrm{w}$ ich doborze pomocni są czytelnicy - fani sztuki komiksowej. Biblioteka pracuje w systemie Sowa TCP w architekturze klient/serwer. Katalogujący umieszczają w opisach bibliograficznych hasła scenarzystów, ilustratorów i tłumaczy, nie uwzględniając w nich osób odpowiedzialnych za wypełnianie tuszem, za kolory itd. ${ }^{16}$.

Z powyższych uwag wynika, że głównym problemem jest odpowiedni dobór haseł. Kto jest ważniejszy: autor tekstu czy ilustracji, a może pomysłodawca (bo czasem to zupełnie inna osoba)? Nie ma jednoznacznej odpowiedzi.

Decyzja o wyborze hasła głównego w cyklach autorskich może być brzemienna w skutki. Jeśli nie sprawdzi się, jakie jest autorstwo całości, łatwo popełnić błąd już na starcie. Przykład: cykl opowieści Lucky Luke. Większość tomów tworzył duet Morris\&Goscinny, z tym że kolejność twórców często podawana była przypadkowo. Hasło dla cyklu utworzono od nazwiska Goscinnego. Według tomu, który był podstawą tworzenia hasła - prawidłowo. Dopiero przy opracowaniu kolejnych tomów cyklu okazało się, że prawdziwym twórcą całości był ilustrator, scenarzyści zaś rzadko, ale jednak się zmieniali.

${ }^{14}$ A. Kałudzka, Temat: Re: Komiksy w bibliotece [online] Do: A. Kowalska, 12.12.2009; 13:05 [cytowany 20.04.2010]. Korespondencja osobista.

${ }^{15}$ P. Noga, Temat: Re: Komiksy w bibliotece [online] Do: A. Kowalska, 5.01.2010; 10:48 [cytowany 20.04.2010]. Korespondencja osobista.

${ }^{16}$ T. Mackojć, Temat: Re: Komiksy w bibliotece [online] Do: A. Kowalska, 15.12.2009; 12:50 [cytowany 20.04.2010]. Korespondencja osobista. 
Podobny problem pojawił się w opracowaniu serii komiksowej Thorgal. Scenariusz do niej wymyślił Jean van Hamme, natomiast ilustracje wykonywał Grzegorz Rosiński, którego van Hamme poprosił o współpracę. Od któregoś tomu zmienia się nazwisko scenarzysty. Rolę dotychczasowego autora teksu przejmuje Yves Sente, natomiast autor ilustracji pozostaje ten sam. W związku z tym poprawne było stworzenie hasła serii autorskiej dla Grzegorza Rosińskiego, który jest autorem ilustracji dla wszystkich tomów. Problemu nie stanowiła z kolei seria Sandman Neila Gaimana, ponieważ $\mathrm{w}$ tym przypadku scenariusz stworzył jeden autor, zmieniali się ilustratorzy. W związku z tym Gaiman występuje w opisach w haśle głównym, dla niego również utworzone zostało hasło serii autorskiej, natomiast ilustratorzy otrzymują hasła dodatkowe.

Nie ma niestety niezawodnej reguły, która określałaby konieczność stosowania takiego a nie innego hasła w przypadku tworzenia opisu bibliograficznego opowieści graficznych. Katalogerzy stosują zasadę, zgodnie $\mathrm{z}$ którą $\mathrm{w}$ haśle głównym (pole 100) występuje osoba wymieniona na pierwszym miejscu w katalogowanym dokumencie. Tak więc czasem jest to autor scenariusza, innym razem ilustrator. Wszystko zależy od tego, co zdaniem wydawcy komiksu jest rzeczą istotną dla danego dokumentu. Dlatego właśnie często nie jest do końca pewne, czy główną rolę w stworzeniu opisywanego komiksu odegrał autor, którego podaje się w haśle głównym (pole 100) jako najważniejszego, czy ten właśnie, który otrzymał hasło dodatkowe (pole 700).

Okazuje się, iż problem z ustaleniem rangi autorstwa (scenarzysta czy ilustrator?) jest zasadny. Wydawać by się mogło, iż autorami historyjek obrazkowych są osoby, które je wymyśliły i narysowały. W rzeczywistości jednak jest tak, że nie wszystkie komiksy podpisywane były przez ludzi, którzy je naprawdę rysowali. Pojawiały się i takie, które publikowano anonimowo. Wynikało to z faktu, iż wydawcy nierzadko odkupywali prawa autorskie od twórców opowieści, następnie zaś powierzali rysowanie kolejnych odcinków seriali różnym twórcom. Praktyka doprowadziła do pojawienia się wąskich specjalizacji, polegających na tym, że jedna osoba wykonuje rysunek ołówkiem (penciler), druga pociąga go tuszem (inker), trzecia wpisuje teksty w dymki (letterer), czwarta nakłada kolor (colorist). Działo się tak głównie wtedy, gdy znakiem rozpoznawczym był tytuł (Superman, Batman) $)^{17}$. Obecnie nazwiska wszystkich osób współtworzących komiks umieszczane są na dokumencie $\mathrm{w}$ formie nazwy właściwej, bądź też pseudonimu.

W związku z tym nie ma trudności w ustaleniu autorstwa, kłopot stanowi tylko odpowiedni dobór haseł. W rekordach bibliograficznych hasła

${ }^{17}$ J. Szyłak, Komiks, s. 32-33. 


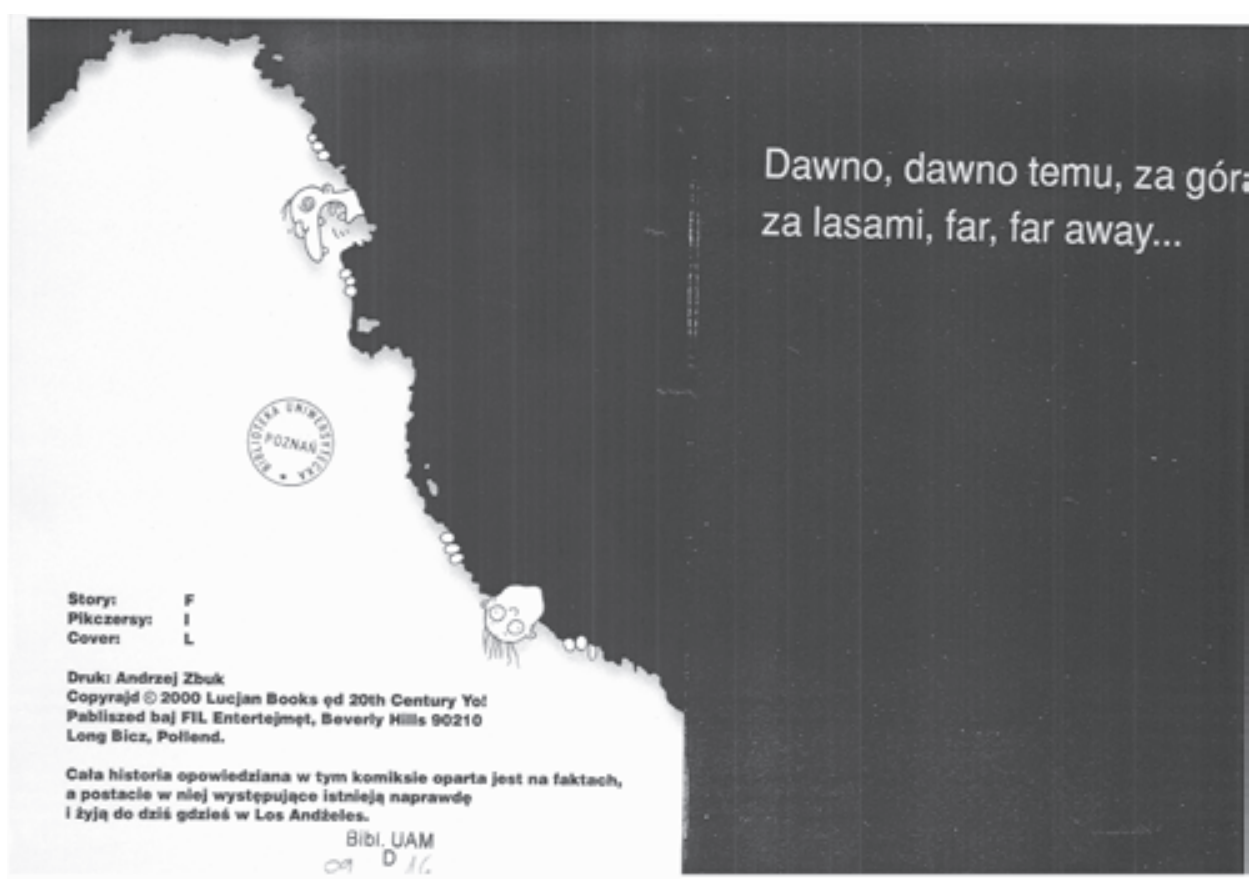

Il. 1. Strona redakcyjna komiksu Gwiezdna nabojka (story, pikczersy, cover: Fil. - [S.1., 2001])

główne i dodatkowe otrzymują autorzy scenariusza i ilustracji, natomiast kolejność ich występowania w opisie bibliograficznym związana jest $\mathrm{z}$ intencją wydawniczą. Informacje o pozostałych osobach - odpowiedzialnych za kolory, okładkę, obrys tuszem, separację kolorów itd. - zostają umieszczone w polu uwag. Na doborze haseł jednak nie kończą się trudności.

Kiedy bierze się do ręki komiks, często uderza mnogość zamieszczonych w nim i na nim informacji. Poza tytułem, autorami scenariusza i ilustracji oraz tłumaczem znajdują się tam również dane dotyczące serii, w której komiks się ukazuje, nazwiska twórców postaci oraz - w przypadku, gdy komiks jest tłumaczeniem $\mathrm{z}$ innego języka - dane związane $\mathrm{z}$ wydaniem oryginału (tytuł, wydawca, miejsce wydania). Informacje odnoszące się do dzieła oryginalnego oraz o kreatorze głównego bohatera zamieszcza się w polu uwag, by użytkownik uzyskał możliwie najwięcej danych dotyczących konkretnego tytułu.

Problem pojawia się natomiast, jeśli przyjrzymy się bliżej kwestii serii wydawniczej. Często zdarza się, iż pomimo tego, że na dokumencie znajdzie się słowo „seria”, nie można zakwalifikować dokumentu do grupy dzieł wydawanych w serii z punktu widzenia przepisów katalogowania. Nierzadko wydawca podaje na stronie redakcyjnej informację, która 
I1. 2. Strona tytułowa komiksu Pora moiet, cz. 1 (scen. Neil Gaiman. - Warszawa, cop. 2004)

\section{SANDMAN}

PORA MGIEE część 1

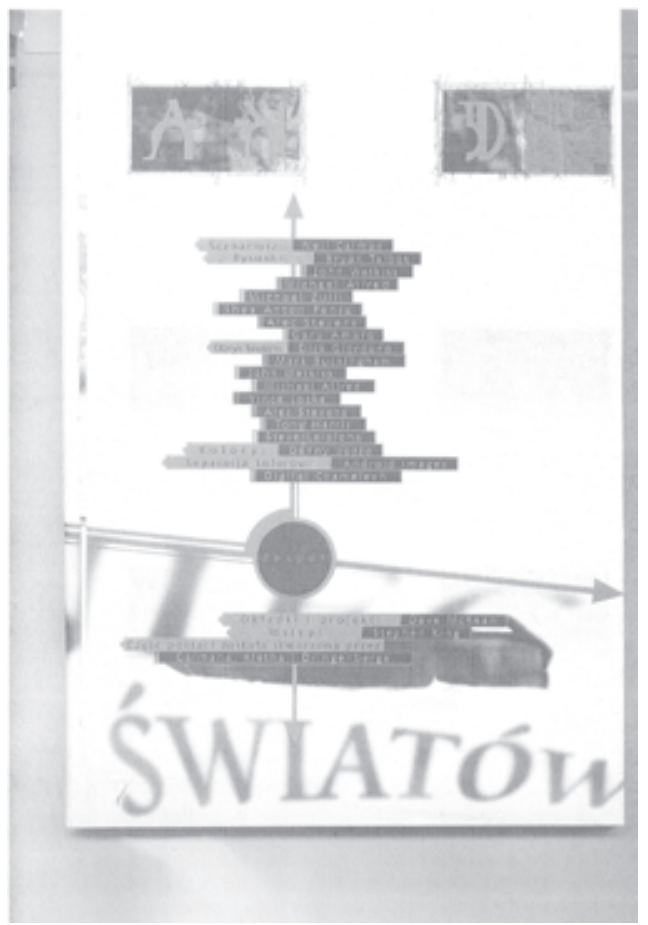
cop. 2006) 
świadczy o tym, że katalogowana pozycja wydawana była w serii X lub Y, natomiast jeśli przyjrzeć się bliżej tytułowi oryginału, okazuje się, że rzekoma seria musi być rozpatrywana jako tytuł autonomiczny i podana w polu 245 rekordu bibliograficznego. Jako przykład może posłużyć tytuł Batman, rok pierwszy Franka Millera (tytuł oryginału Batman, year one). Początkowo padały propozycje utworzenia hasła dla serii autorskiej, lecz po dokładniejszym obejrzeniu dokumentów okazało się, iż istnieją co najmniej trzy powody, dla których utworzenie hasła serii staje się niemożliwe:

- każdy tytuł to inna historia,

- obok Franka Millera istnieje wielu innych autorów komiksów o Batmanie, jak choćby Brian Azzarello (Batman, rozbite miasto) czy Max Allan Collins (Batman: scar of the bat),

- tytuł oryginału wyraźnie wskazuje na nierozerwalność tytułu głównego z podtytułem, nie można więc sztucznie rozdzielić tytułu, by utworzyć hasło dla serii.

Wśród komiksów, które z różnych względów są bardzo kłopotliwe, znajdują się także tzw. fanziny, czyli niskonakładowe pisma, rozpowszechniane od drugiej połowy lat 70. XX wieku w kręgach miłośników różnych dziedzin, przede wszystkim muzyki rozrywkowej i literatury fantastycznej ${ }^{18}$. Trudność w opracowaniu fanzinów polega na tym iż, w przeciwieństwie do tradycyjnych komiksów, zawierają niewystarczającą liczbę danych wydawniczych, które są istotne dla katalogujących. Często brakuje miejsca wydania, wydawcy bądź roku wydania. Wynika to z faktu, iż dokumenty takie wydawane są za pomocą prostych technik poligraficznych i rozpowszechniane poza obiegami oficjalnymi - na spotkaniach, imprezach, drogą korespondencyjną itp.

Przykładem takiego fanzinu jest Zimowy templariusz Igora Myszkiewicza, w którym na stronach tytułowej i redakcyjnej oraz na okładkach nie ma podstawowych informacji wydawniczych. W takich przypadkach najczęściej poszukuje się brakujących danych na stronach lub blogach internetowych, a informacje o źródle, na podstawie którego je znaleziono, umieszcza się $\mathrm{w}$ opisie, w odpowiednim polu podając adres strony. Zdarzają się też komiksy, jak np. Co mówiłem, durniu? Godai'ego, w których najbardziej kłopotliwe jest podjęcie decyzji w sprawie zakwalifikowania ich do odpowiedniej grupy wydawnictw: zwartych bądź ciaggłych - co jest istotne w momencie opracowywania danego tytułu. W fanzinie brakuje też podstawowych danych wydawniczych, zaś na stronie redakcyjnej znajduje się adnotacja dotycząca częstotliwości ukazywania się tego tytułu. Po przejrzeniu całości katalogujący nie jest jednak pewien, czy ma

${ }^{18}$ Podręczny słownik terminów literackich, red. J. Sławiński, Warszawa 1999, s. 89. 


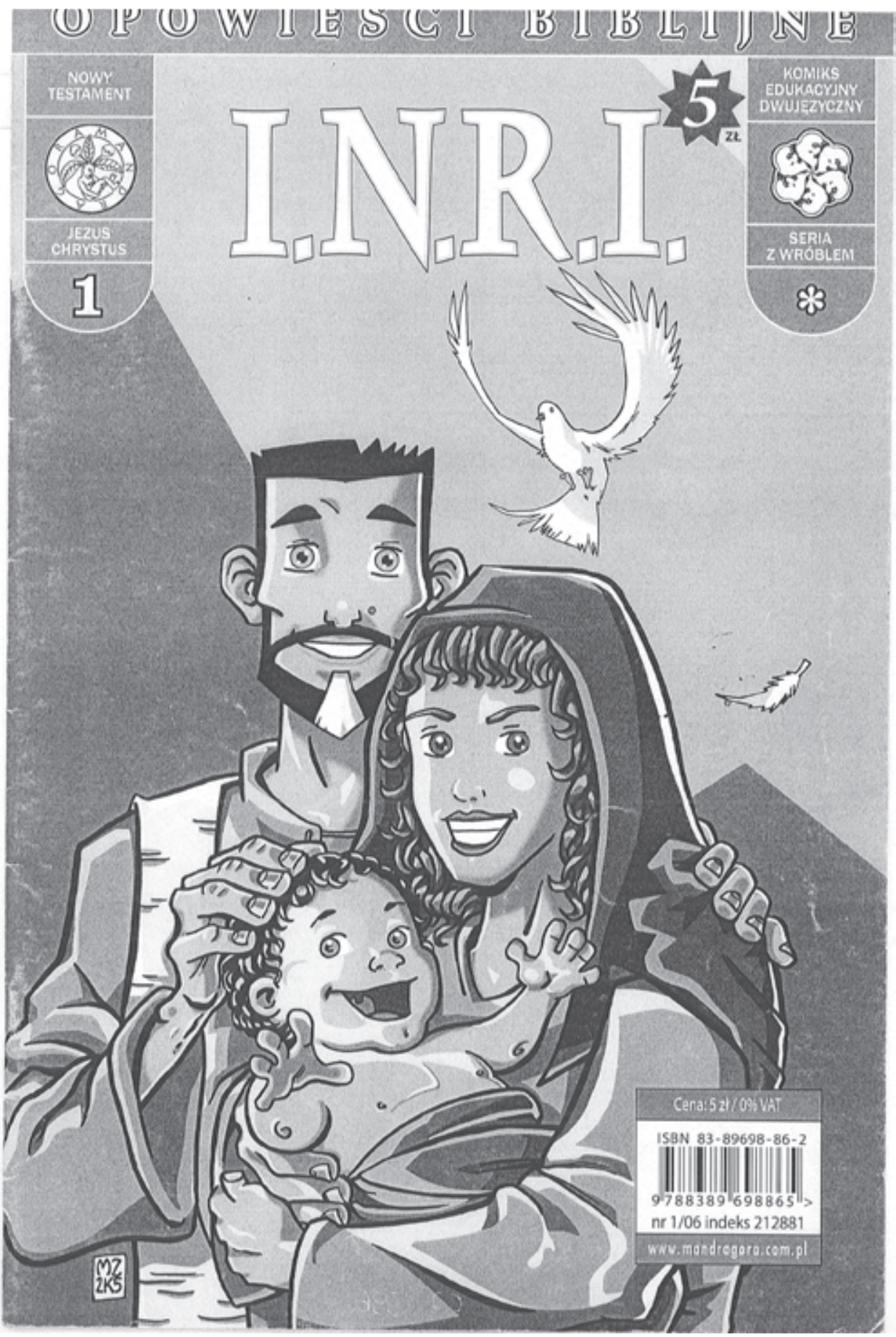

Il. 4. Strona tytułowa komiksu I.N.R.I.: opowieści biblijne, Nowy Testament, Jezus Chrystus. 1 ([scen.: Tobiasz Piątkowski]. - Warszawa, cop. 2006) 
przed sobą czasopismo, czy też wydawnictwo zwarte. Nierzadko wymagana jest konsultacja specjalistów z dwóch oddziałów: opracowania dokumentów zwartych i opracowania dokumentów ciągłych, by decyzja nie została podjęta pochopnie.

Każdy nowy komiks w Bibliotece Uniwersyteckiej to wyzwanie, gdyż w większości z nich pojawia się coś nowego, z czym nie miało się do czynienia wcześniej. Pomocne są strony internetowe (Gildia Komiksu, Zeszyty Komiksowe, Miasto Fantastyki, KZ - Magazyn Miłośników Komiksu, Wielkie Archiwum Komiksu, Powszechna Baza Recenzji), które zamieszczają ważne informacje, będące uzupełnieniem danych znajdujących się w katalogowanym dokumencie. Ważnym źródłem informacji są również: wspominana wcześniej Bibliografia komiksów. Misiory oraz blogi internetowe: „Kolorowe Zeszyty” czy „Przypadkiem”.

W związku z problemami, które pojawiają się w czasie opracowywania komiksów, wydaje się zasadne stworzenie nowej normy dla opisu bibliograficznego komiksów. Takie rozwiązanie ułatwiłoby pracę katalogującym, a co najważniejsze, umożliwiłoby ujęcie wszystkich osób odpowiedzialnych za powstanie danego komiksu. Istniejąca norma nie dopuszcza stosowania haseł dla wszystkich autorów, jeśli jest ich więcej niż trzech, co dla opisu opowieści graficznych byłoby bardzo istotne. Każda osoba tworząca komiks jest ważna, ponieważ każda decyduje o jego kształcie i wyglądzie. Ze względu na wymagania przepisów może zdarzyć się taka sytuacja, iż osoba, która włożyła najwięcej pracy w powstanie ilustracji lub jakości danego tytułu, zostanie pominięta w opisie, gdyż wydawca ujął ją na czwartym bądź kolejnym miejscu na stronie tytułowej lub redakcyjnej. Warto zastanowić się również nad wprowadzeniem obowiązku tworzenia haseł dla wszystkich odpowiedzialności, a więc nie tylko scenarzystów i ilustratorów, lecz również autorów odpowiedzialnych za tusz, okładkę, separację kolorów i innych. Taki opis z pewnością różniłby się wyglądem od opisu bibliograficznego książki, głównie ze względu na liczbę zastosowanych w nim haseł, ale umożliwiałby dotarcie do każdego tytułu przez wszystkie odpowiedzialności w komiksie.

Można zaryzykować stwierdzenie, że dziś „apetyt” Biblioteki Uniwersyteckiej na miniburgera został zaspokojony, a katalogerzy - zdaje się znaleźli już dobry „przepis” na jego przyrządzenie. 


\section{Przykładowe rekordy bibliograficzne w formacie MARC 21:}

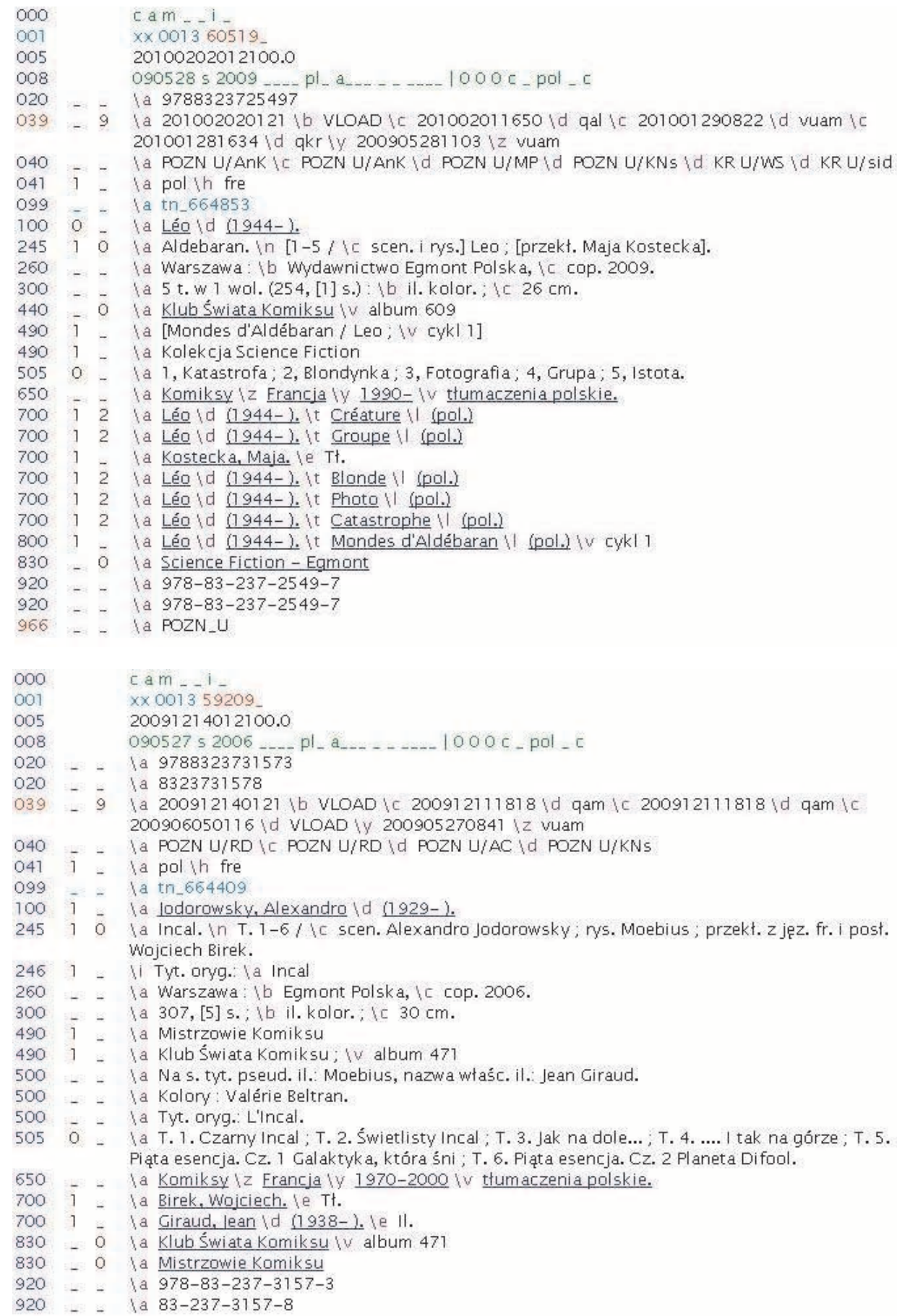




\title{
AGNIESZKA SZCZECIŃSKA, ANNA KOWALSKA
}

\section{A lust for a "miniburger". On problems encountered during library processing of comic books in MARC 21 format}

\begin{abstract}
Poznań University Library has been collecting comic books and other relevant material since 2007. A conducive opportunity for the decision to collect comics publications was a purchase of a private collection of 4,670 comic books the very same year. The present article introduces the reader to the notion of "comic book" or "comics" and discusses problems in formal processing that face cataloguers of this difficult material. The authors compare different solutions to the problem applied in other libraries and present the current state of affairs in comics cataloguing at Poznań University Library. The article is complemented with specific examples and particular solutions to be applied in the near future.
\end{abstract}

KEY wORDS: comic book, cataloguing. 